doi $10.15826 /$ recon.2021.7.2.012

UDC 331

JEL J01, J24, J21

\title{
Digitalization in the development of human resource management in the Republic of Belarus
}

\author{
M. Tawbe \\ ${ }^{1}$ Belarusian State Technological University, Minsk, Belarus \\ ${ }^{2}$ NGO organization funded by UNHCR, Beirut, Lebanese Repablic; m.tawbe@outlook.com
}

\begin{abstract}
Relevance. Digitalization has led to a global transformation in the field of human resource management. Modern HR professionals view their roles not as mere administrators but as strategic enablers for key organizational decisions. In this scenario, there is a need to describe a digital system for efficient HR management (HRM) which is able to improve the skills of the employees. Research objective. The purpose of this study is to analyze the current state of the labor market in the Republic of Belarus and assess how digitalization affects human resource management strategies Data and methods. The article used the method of comprehensive data analysis in the study of the labor market in Belarus. The systemic approach was used to describe the strategy of HR digitalization. The official data of the Statistical Committee of the Republic of Belarus are used as the source of information. Results. The article analyzes the labor market in the Republic of Belarus. The factors that should be taken into account in the formation of human resource management strategy have been identified. The introduction of information and communication technologies in the country's enterprises was assessed and conclusions about the prospects of digital technology in human resource management were made. This work explains a strong relationship between the technological progress and HRM in organizations and companies. The paper shows how innovation can lead to a more proficient administration in HRM and improve the overall performance of the workforce. Several main zones of digitalization and its effects on human asset development are described. Conclusion. HRM has been changed by the advancement of the digital era. HR professionals no longer have to engage in manual procedures or deal with overwhelming volumes of data. With modern innovative solutions that enhance human resource management and growth, HR teams have greater freedom to shape organizational culture and productivity. The introduction of technology in human resource management offers great opportunities to optimize company resources and maximize results.
\end{abstract}

\section{KEY WORDS}

technology, human resource management, technological development, improvement, efficiency, automation, innovation

\section{FOR CITATION}

Tawbe, M. (2021) Digitalization in the development of human resource management in the Republic of Belarus. R-economy, 7(2), 133-141. doi: $10.15826 /$ recon.2021.7.2.012

\section{Цифровизация в развитии управления кадровыми ресурсами в Республике Беларусь}

\author{
M. Таубе \\ ${ }^{1}$ Белорусский государственный технологический университет, Минск, Республика Беларусь \\ ${ }^{2}$ НПО, финансируемая УВКБ ООН, Бейрут, Ливанская Республика; m.tawbe@outlook.com
}

\begin{abstract}
АННОТАЦИЯ
Актуальность. Цифровизация привела к глобальной трансформации в области управления кадровыми ресурсами. Современные специалисты по персоналу рассматривают свои роли не просто как администраторов, а как стратегические факторы, способствующие принятию ключевых организационных решений. В этом сценарии необходимо описать цифровую систему для эффективного управления персоналом (HRM), которая способна улучшить навыки сотрудников. Цель исследования. Целью данного исследования является анализ текущего состояния рынка труда в Республике Беларусь и оценка того, как цифровизация влияет на стратегии управления кадровыми ресурсами. Данные и методы. В статье использован метод комплексного анализа данных при исследовании рынка труда (C) Tawbe, M., 2021
\end{abstract}

\section{КЛЮЧЕВЫЕ СЛОВА}

технологии, управление человеческими ресурсами, технологическое развитие, совершенствование, эффективность, автоматизация, инновации 
Беларуси. Системный подход использован для описания стратегии цифровизации HR. B качестве источника информации используются официальные данные Статкомитета Республики Беларусь. Результаты. В статье анализируется рынок труда в Республике Беларусь. Выявлены факторы, которые необходимо учитывать при формировании стратегии управления кадровыми ресурсами. Проведена оценка внедрения информационно-коммуникационных технологий на предприятиях страны и сделаны выводы о перспективах цифровых технологий в управлении кадровыми ресурсами. Эта работа объясняет тесную взаимосвязь между технологическим прогрессом и HRM в организациях. Показано, как инновации могут привести к более эффективному администрированию в области управления человеческими ресурсами и улучшить общую производительность труда. Описаны несколько основных зон цифровизации и ее влияние на развитие человеческого капитала. Выводы. Управление кадровыми ресурсами изменилось с наступлением цифровой эпохи. Специалистам по персоналу больше не нужно выполнять ручные процедуры или иметь дело с огромными объемами данных. Благодаря современным инновационным решениям, которые улучшают управление человеческими ресурсами и их рост, HR-команды имеют больше свободы в формировании организационной культуры и производительности. Внедрение технологий в управление кадровыми ресурсами открывает большие возможности для оптимизации ресурсов компании и достижения максимальных результатов.

\section{FOR CITATION}

Tawbe, M. (2021) Digitalization in the development of human resource management in the Republic of Belarus. R-economy, 7(2), 133-141. doi: $10.15826 /$ recon.2021.7.2.012

\section{Introduction}

Digitalization is one of the modern trends that has a direct impact on the nature of labor relations and the state of employment in various states and regions. Labor market and human resource management are urgent issues for the social sphere in any state (Rebolledo \& Vega, 2021).

The term "human resources" refers to individuals employed in an organization to carry out different jobs in exchange for wages and other benefits. Human Resource Management (HRM) is "the comprehensive set of tasks concerned with developing and maintaining a qualified workforce in ways that contribute to organizational effectiveness" (Jamrog \& Overholt, 2004).

Recently HRM has been witnessing dramatic changes, forcing it to become more responsive to the demands of the fast evolving business world. Whereas HRM was once seen as a support company center, it now plays a key role in the business success. HRM has been affected by a number of factors that have contributed to the changes in the role it plays in an organization (Denisi \& Griffin, 2008)

Fierce competition, globalization, and economy based on intangibles are the factors that determine employee knowledge and corporate culture and have created a challenging environment for the organizations in the twenty-first century. This has led organizations to the realization that the main competitive advantage they can gain and control is related to acquiring and retaining competent peo- ple. Hence, HRM has become an essential function in management, and efforts invested in people are to be aligned with the organization strategy. Technology plays a vital role in achieving this goal.

The process of digital transformation in $\mathrm{Be}$ larus is defined as one of the most important factors in ensuring the competitiveness and innovative development of both individual organizations and the national economy. Thus, the State Program of Digital Economy and Information Society Development for 2016-2020 has three subprograms: "Information and Communication Infrastructure", "Infrastructure of Informatization" and "Digital Transformation"1.

The relevance of the problem of improving the efficiency of HRM in Belarus is determined by the trends in labour market, which are associated with a decrease in the population as a whole and a decline in the labour force in particular. Thus, while in 2015 the working-age population in Belarus amounted to 5,444,800 people, in 2019 it will be $5,368,000$ people. In just four years (2016-2019), the labour force of the Republic decreased by 145.9 thousand people, or 2.5 per cent. Similar trends were observed in the employed population. Over the four years of the 5-year period, the number of people employed in the national economy decreased by $3.6 \%$, or 161.8 thousand people 2 .

${ }^{1} \mathrm{~N} 5 / 41866$ "State digital economy and information society development programme for 2016-2020". 28 March 2016.

${ }^{2}$ December 30, 2020 № 777 On the State program “Labor Market and Employment Promotion" for 2021-2025. 
The purpose of this study is to show how the digital age is changing human resource management. Therefore, we are going to address the following tasks: characterize the labor market in Belarus and its current challenges and investigate the impact of digitalization on HR management in Belarussian enterprises.

\section{Theoretical framework}

E-HRM/Digital HRM is a method of actualizing HR methodologies, strategies, and practices through web-based channels (Swaroop, 2012). E-HRM can range from essential staff records to complex sub-networks. Today the greater part of these systems are computerized networks. The labor data network contains fundamental data that can be supplemented by some other business information. With most data set networks, there is a possibility to process information and present it in the required way.

E-HRM is a method of executing HR methodologies, strategies, and practices in association with the full utilization of innovative networks. A quarter of organizations believe that e-HRM is necessary, while more than a half say it is of medium importance. (Zafar, 2010). By and large, efforts have been made to develop the understanding of e-HRM as a theoretical umbrella term referring to HRM methodology in the digital era. This definition has customarily addressed the usage and implementation of the technological HR changes and, as a product of this process, the creation of networked HR structures covering the entire corporation. (Strohmeier, 2007).

Boundarouk and Ruël (2009) point out the need to devise a concept that would link together HRM and IT, recognizing the importance of both workers and IT administrators.

E-HRM is gaining more and more significance at present (Cedar Crestone, 2005). The more corporations embrace e-HRM, the more efficient their performance becomes (CedarCrestone, 2005; Zarkan, 2017). According to Esen and Erdogmus (2011), advancements in HR administration allow companies to develop their competitive edge. The three main advantages of e-HRM are cost cutting, enhancing HR benefits, and improving company strategy (Brockbank, 1997; Lepak and Snell, 1998; Stanton and Coovert, 2004).

IT assists in two fields of e-HRM. First of all, the internet coordinates and links individuals across various regions and countries. Secondly, IT can be used by HR managers, covering some part of their job processes or all of them. Voermans and van Veldhoven (2007) describe e-HRM as the regulatory help of HR work in associations based on utilizing network technology.

Tomashevsky (2020) explores the transformation processes in individual and collective labor relations in Belarus as a result of the impact of digital technologies. However, the author does not focus on the need for a strategic approach in HRM.

\section{Methodology}

The paper applies a method of analytical analysis based on the study of existing technologies in HR management.

The first step of the study characterizes the labor market in Belarus, followed by a comparison of employment indicators with the neighboring countries. Next, the article describes the technologies used in HR management, which have a significant impact on the business processes of companies; it proposes a strategy for HR digitalization, the implementation of which will make HR management an effective tool to help companies succeed. The third step describes the development of digitalization in HR management in Belarus and the prospects for its further development.

The data from Decision No. 777 of the Council of Ministers of the Republic of Belarus on the State Programme "Labour Market and Employment Promotion" for 2021-2025 of 30 December 2020 and the 2016-2019 Commonwealth of Independent States National Labour Market Monitor were used to analyze the labor force in Belarus.

\section{Results and Discussion}

The digitalization of HRM can help corporations gain competitive advantages over their counterparts that do not use digital technologies in their HRM. In addition, the use of modern technologies increases the efficiency and effectiveness of HRM in general.

\section{Labour force analysis in Belarus}

The reduction in the number of workers, which takes place against the background of relative stability of production, makes the situation in the labour market in Belarus more "worker-friendly". The relatively high stability of the labour market in Belarus, as compared to other EEU countries, is evidenced by the data in Table 1 . 
Ensuring employment of the population is a priority in the social policy of the Belarusian state. The state is taking measures to gradually improve the situation in the labour market (Table 2). As a result of the work of the state employment service, 740,000 people were employed from 2015 to $2020,40,000$ people were trained and 9,000 people were supported to start their own business ${ }^{3}$.

Considering the quite balanced labor market in Belarus and the state protection of workers, it is especially important for companies to choose the right HRM strategy. For a more comprehensive picture, the systematization of views and approaches to the problems of HRM in a situation where these resources are scarce in the labor market is of fundamental importance. Therefore, the introduction of modern technologies in HRM can play a crucial role in achieving efficiency in this sphere.

${ }^{3}$ Official site Ministry of Labour and Social Protection of the Republic of Belarus. (15.06.2021). Available at: http://www. mintrud.gov.by/ru/Rynok truda dostijeniya i celi2025/
In this case, HR services will gradually become centers for the development and implementation of HR strategy. Factors that should be considered in the formation of HRM strategy include HRM priorities in relation to the goals of this or that enterprise; the degree of employees' dissatisfaction with their work; the enterprise's personnel potential; the efficiency of HRM (degree of goal achievement); and the dynamics of labor productivity indicators, economic efficiency, and indirect indicators of HRM efficiency.

\section{Implementation of information technologies in the enterprises of the Republic of Belarus}

In recent years, Belarusian enterprises have made significant progress in creating information systems and resources. A significant part of the document flow has been converted into electronic form, state statistical, departmental and tax reporting has been automated, electronic invoices, the electronic system of fiscal procedures, the marking goods system have been introduced, and conditions for electronic interaction between the state and business have been created (Table 3 ).

Labor market indicators in Belarus in 2019

Table 1

\begin{tabular}{|l|c|c|c|c|}
\hline & $\begin{array}{c}\text { Unem- } \\
\text { ploy- } \\
\text { ment } \\
\text { rate* }^{*}\end{array}$ & $\begin{array}{c}\text { Youth } \\
\text { unem- } \\
\text { ployment } \\
\text { rate** }\end{array}$ & $\begin{array}{c}\text { Number of unemployed registered } \\
\text { with state employment services } \\
\text { employment services (in \% of labor } \\
\text { force/ economically active population) }\end{array}$ & $\begin{array}{c}\text { Economically active population) Ratio of regis- } \\
\text { tered unemployed to number of vacancies report- } \\
\text { ed by employers to public employment services } \\
\text { (at the end of the year; per 100 vacancies) }\end{array}$ \\
\hline Belarus & 4.1 & 10.2 & 0.2 & 11 \\
\hline Armenia & 18.4 & 31.9 & $\mathrm{~N} / \mathrm{A}$ & 1712 \\
\hline Kazakhstan & 4.8 & 3.6 & 1.1 & $\mathrm{~N} / \mathrm{A}$ \\
\hline Kyrgyzstan & 5.5 & 12.8 & 3.0 & 1713 \\
\hline Russia & 4.6 & 15.5 & 0.9 & 47 \\
\hline
\end{tabular}

Note: *Unemployed people aged 15-64, as \% of labour force/economic active population economically active population of the respective age; ILO(International Labor Organization) methodology; ** Unemployed people aged $15-24$ years as \% of respective age group workforce/economically active population; ILO methodology economically active population of the relevant age; ILO methodology

Source: Commonwealth of Independent States National Labour Market Monitoring, 2016-2019. Interstate Statistical Committee of the CIS. Moscow; 2020, pp. 51.

Table 2

State measures to reduce unemployment in Belarus

\begin{tabular}{|l|c|c|}
\hline & $\begin{array}{c}\text { The number of unemployed who received vocational } \\
\text { training by referral from state employment services (by } \\
\text { the end of the year; as \% of the number of unemployed) }\end{array}$ & $\begin{array}{c}\text { The number of unemployed who took part } \\
\text { in paid public works (by the end of the year; } \\
\text { as of the number of unemployed) }\end{array}$ \\
\hline Belarus & 10.6 & 22.2 \\
\hline Armenia & 0 & 0.1 \\
\hline Kazakhstan & 6.2 & 3.2 \\
\hline Kyrgyzstan & 1.4 & 0.3 \\
\hline Russia & N/A & N/A \\
\hline
\end{tabular}

Source: Monitoring the state of national labor markets of the Commonwealth of Independent States, 2016-2019. Interstate Statistical Committee of the CIS/. Moscow; 2020, pp. 51. 
Table 3

The main indicators of digitalization in organizations in Belarus

\begin{tabular}{|l|c|c|c|c|c|c|c|c|}
\hline & \multicolumn{4}{|c|}{ Total } & \multicolumn{3}{c|}{ As a percentage of the total number of organizations } \\
\cline { 2 - 9 } & $\mathbf{2 0 1 5}$ & $\mathbf{2 0 1 6}$ & $\mathbf{2 0 1 8}$ & $\mathbf{2 0 2 0}$ & $\mathbf{2 0 1 5}$ & $\mathbf{2 0 1 6}$ & $\mathbf{2 0 1 8}$ & $\mathbf{2 0 2 0}$ \\
\hline $\begin{array}{l}\text { Number of surveyed organi- } \\
\text { zations }\end{array}$ & 7829 & 7960 & 8080 & 8617 & 100 & 100 & 100 & 100 \\
\hline $\begin{array}{l}\text { Of which used: } \\
\text { E-mail }\end{array}$ & 7584 & 7707 & 7776 & 8480 & 96.9 & 96.8 & 96.2 & 98.4 \\
\hline local area networks & 6411 & 6532 & 6444 & 6745 & 81.9 & 82.1 & 79.8 & 78.3 \\
\hline Internet & 7611 & 7755 & 7819 & 8506 & 97.2 & 97.4 & 96.8 & 98.7 \\
\hline Intranet & 1819 & 1878 & 2150 & 2375 & 23.2 & 23.6 & 26.6 & 27.6 \\
\hline Extranet & 678 & 737 & 1091 & 1264 & 8.7 & 9.3 & 13.5 & 14.7 \\
\hline Had a website on the Internet & 4670 & 4955 & 5433 & 6063 & 59.7 & 62.2 & 67.2 & 70.4 \\
\hline
\end{tabular}

Source: National Statistical Committee of the Republic of Belarus. Available at: https://www.belstat.gov.by/ofitsialnaya-statistika/makroekonomika-i-okruzhayushchaya-sreda/informatsionno-telekommunikatsionnye-tekhnologii/

Recently, there has been a growth in ICT organizations in Belarus, which suggests the introduction of ICT in various areas of the economy, including the labor market (Table 4). ICT (information and communication technology) is defined as the use of computers and other digital technologies to help individuals, businesses, and other institutions process or use information (Jain, 2021).

National ICT industry in Belarus

Table 4

\begin{tabular}{|l|l|l|l|l|l|l|}
\hline Indicator name & 2014 & 2015 & 2016 & 2017 & 2018 & 2019 \\
\hline
\end{tabular}

\begin{tabular}{|l|l|l|l|l|l|l|l|}
\hline ICT sector, units & 4228 & 4536 & 3962 & 4492 & 4996 & 5202 \\
\hline Content and
\end{tabular}

\begin{tabular}{|l|c|c|c|c|c|c|c|}
\hline Content and Media & - & - & 998 & 987 & 968 & 988 \\
\hline
\end{tabular}

Sector, units

Source: National Statistical Committee of the Republic of Belarus. National Statistical Indicators of Digital Economy Development in the Republic of Belarus. Available at: https:// www.belstat.gov.by/ofitsialnaya-statistika/makroekonomika-i-okruzhayushchaya-sreda/informatsionno-telekommunikatsionnye-tekhnologii/tsifrovaya-ekonomika/

Despite the increase in the number of ICT companies, there is a need to develop a strategy for further digitalization in the field of human capital management, as well as in the coordination of employees in the work process in the context of digital transformation. In our opinion, this strategy has not been developed in the Republic of Belarus, which makes it a vital problem that needs to be addressed.

The strategy of digital transformation in the HR management system should contain not only the main principles and areas, ways and means of achieving the strategic objectives of HR digitalization, but also reflect the factors and conditions necessary to implement this process. The goal of such a strategy is to improve the or- ganization's performance through productivity growth and development of employees' innovative potential.

\section{HR management technology in the digital age}

Technology has been shaping HRM, both on the departmental and organizational level. The research literature has shown the pivotal role of technology in strategic HR; digital systems are considered as one of the necessary tools that help making HRM a strategic function in an organization. Among other things, technology was supposed to make the administrative aspect of HR more efficient. At the same time, the experience of many organizations has revealed that automated HRM is not exactly a panacea, as it also brings many challenges (Shuler \& Jackson, 2007).

The following technologies have had a significant and direct impact on all business sectors:

1. Electronic recruitment. The impact of digitalization on the recruitment process reduced the significance of old methods of advertising jobs in local newspapers and led to the introduction of online platforms in business, which enabled communication via the internet. The direct link between the applicant and the recruiting company without mediators resulting in increased communication efficiency.

2. Training. It can be a fast track strategy to implement new software into every organization, which includes training employees. While some workers have the unique software processing skills needed by their business, others must be trained. This strategy involves training for new employees who come from smaller businesses and still rely on paper-based contract management and processes. 
3. Electronic management. Electronic management is one of the most important ways of communication between managers and employees to appraise employees' performance, improve and implement the organizational structure of the company. There are many modern systems available to evaluate applicants and determine their capabilities and to find out if they need prior training (Bajer, 2017).

4. Databases and systems of HR and storage. Modern technology has effectively contributed to the reduction of paperwork and time spent on data collection and storage, allowing organizations to improve their efficiency. Technology has further revolutionized the ways to do business, prompting a leadership paradigm shift that has culminated in fresh and creative approaches to doing business with clients, suppliers, and stakeholders.

Many HR researchers pointed out that the diversity of technological characteristics between a technological form or level and another technological form or level may lead to a direct or indirect difference in the characteristics of HR (Ada et al., 2021). This is due to the following reasons:

- a close relationship or connection of every form or level of technology with specific expertise, skills and competencies that must be available in the personnel;

- the technological progress and development is mostly linked to high-level personnel, and high salaries, which requires the organization or company to make the most possible benefit from these human resources, to compensate for the large expenses incurred due to the high salaries and wages that these human resources obtain;

- economic progress imposes the need for high levels of performance, to which human resources operating within the organization or company are committed;

- progress allows a company's human resources to meet the highest standard in line with this technical innovation, and this, in turn, requires the company to prepare its staff by offering a theoretical educational material on this technology before putting the technology into use. Specialized training programs should be applied to raise the productivity of human resources, which involves continuous development in order to avoid any drops or hiccups, which could be caused by the lack of control on the modern technology applied and which affects the quality of the products provided by the organization (Sleezer, Wentling \& Cude, 2007);
- the technological progress often results in an abundance or surplus in the human resources available to a company, which imposes a responsibility on senior departments and human resource departments to optimise the company's workforce. (Sierra-Cedar, 2017-2018) (Table 5).

\section{Strategy of HR digitalization}

Table 5

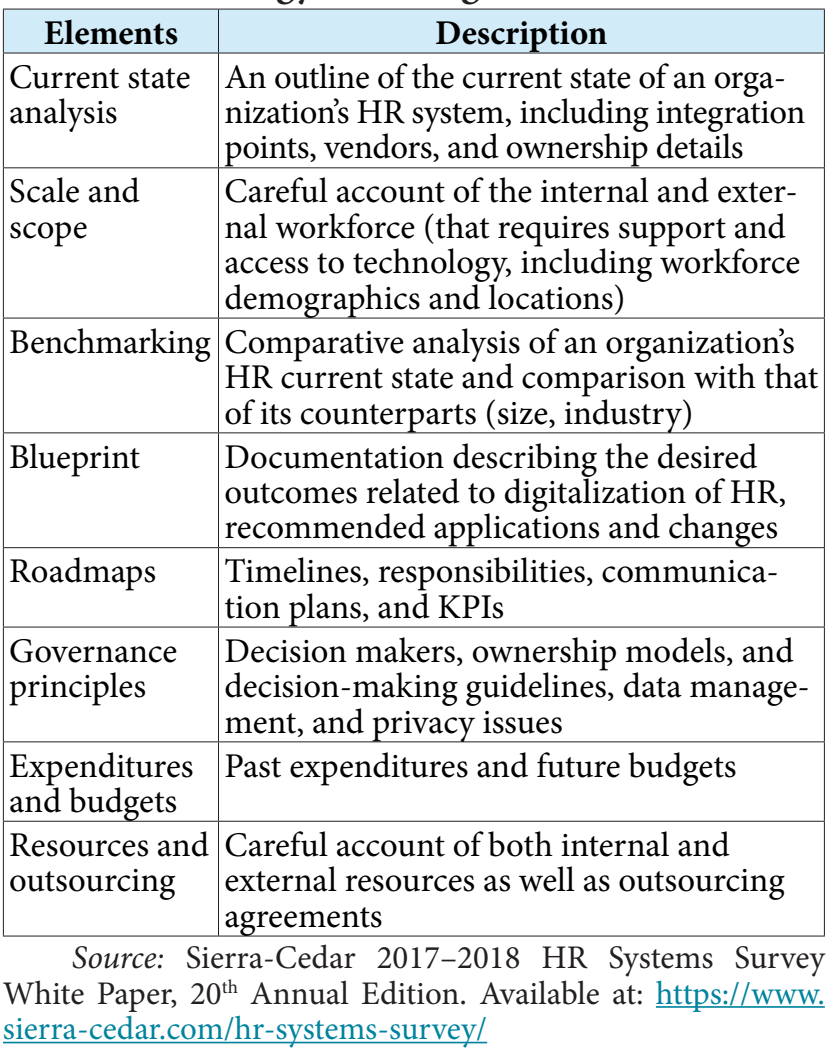

Technology is used to manage human resources and to achieve corporate goals. An HR department can collect a great database that enables it to study, analyze, evaluate and come up with decisions that help develop the company faster during the recruitment and training process (Mathis \& Jackson, 2010)

One of the biggest risks encountered by companies that implement digital technologies is knowledge management and dependence on computers in carrying out normal human tasks. When we automate processes, we find that a person loses control and knowledge of these processes, which negatively affects the management of process knowledge within any organization.

Automation may also increase the risk of fraud. There are common security risks in IT operations, but if automated operations are used, these risks will increase even further, as hackers can take control of an entire organization for ransom. Therefore, change management is part of 
the human-machine relationship in companies, and the more people depend on the machine, the more complex and riskier this relationship becomes (Lengnick-Hall \& Moritz, 2003). The intrinsic interaction between humans, computers and machines will determine the optimal way to combine humans and computers in any institution seeking to advance. It is also imperative that all individuals have access to regular training (for example, on an annual basis).

Risk, security, and data privacy are the topics that are widely discussed in relation to HR and IT. While $48 \%$ of companies report that they are successfully at taking care of Information Security Procedures, developing difficulties from hacked situations and expanded punishments for misusing individual information lead associations to scrutinize their degree of arrangement. Navigating data problems will become a future area of concern as organizations continue to construct personalized HR environments that give actual business analytics as well as personal employee information (Sierra-Cedar, 2017-2018).

\section{Conclusion}

Technology has had a beneficial influence on interior activities of organizations, however it likewise changed the manner in which HR managers assess employee performance. HR information systems enable HRM experts to encourage human asset planning, make choices quicker, clearly describe vacancies, assess employees' performance, and give clear information that executives need. Similarly, digitalization of HRM helps to ensure better communication between the company and its external stakeholders. Innovation has drastically changed how human asset directors train company staff and help them perform their responsibilities more effectively. Teleconferencing enables everybody in the business world to hold meetings online without being tied to locations.

Whether organization consists of employees working remotely, from offices scattered across the globe, freelance workers or combinations of all the three, it faces challenges in ensuring that individuals and teams can connect easily. Without proper solutions in place, productivity will decrease, and departments will become silos instead of connected centers of excellence. From recruitment through retention, HR professionals now have more solutions at their disposal than ever to make HR more efficient and effective. Organizations that wish to compete for and keep the best talent must prioritize technology awareness and skills in their HR departments.

To summarize, it should be noted that the main goal of HRM in the context of digital transformation is to ensure the effective performance of employees in order to move the organization to a new path of development. The digitalization of HR processes will enable organizations to apply a fundamentally new approach to HRM, which will ensure their efficiency and contribute to the development of the creative potential of employees. In this regard, the main task of the Republic of Belarus is to actively implement and apply digital technologies in the national economy in general and in human capital management in particular.

\section{References}

1. Ada, N., Ilic, D., \& Sagnak, M. (2021). A Framework for New Workforce Skills in the Era of Industry 4.0. International Journal of Mathematical Engineering and Management Sciences, 6(3), 771-786. doi: $\underline{10.33889 / \text { IJMEMS.2021.6.3.046 }}$

2. Bajer, J. (2017). Digital transformation needs the human touch. Strategic HR Review, 16(2), 91-92. doi: $10.1108 /$ SHR-02-2017-0011

3. Bondarouk, T., \& Ruel, H. (2009). Challenges in the digital era. The International Journal of Human Resource Management, 20(3), 505-514. doi: 10.1080/09585190802707235

4. Brockbank, W. (1997). HR's future on the way to a presence. Electronic Human Resource Management, 36(1), 65-69. doi: 10.1002/(SICI)1099-050X(199721)36:1\%3C65::AIDHRM11\%3E3.0.CO;2-D

5. CedarCrestone. (2009). CedarCrestone 2009-2010 HR systems survey: HR technologies, service delivery approaches, and metrics ( $12^{\text {th }}$ annual ed.). Alpharetta, GA: CedarCrestone, Inc.

6. Denisi A., \& Griffin R. (2008). Human resource management. $3^{\text {rd }}$ ed. Boston: Houghton Mifflin Company, p. 4. 
7. Esen, M., \& Erdogmus N. (2011). An Investigation of the Effects of Technology Readiness on Technology Acceptance in e-HRM. Procedia - Social and Behavioral Sciences, 24, 487-495 doi: 10.1016/j.sbspro.2011.09.131

8. Imperatori, B. (2017). People Engagement and New Fashions in HRM Practices: Social Responsibility, Digital Transformation, Happiness and Well-Being. In Engagement and Disengagement at Work (pp. 57-90). Springer, Cham.

9. Jain, R. (2021) Information and Communication Technology Adoption and the Demand for Female Labor: The Case of Indian Industry. Journal of Economic Analysis \& Policy, 21(2), 695-722. doi: $\underline{10.1515 / \text { bejeap-2020-0295 }}$

10. Jamrog J., \& Overholt M. (2004) Building a strategic HR function: continuing the evolution. Human Resource Planning, 27(1), 52.

11. Lengnick-Hall, M., Moritz, S. (2003) The Impact of e-HR on the Human Resource Management Function. Journal of Labor Research, 24(3), 365-379. doi: 10.1007/s12122-003-1001-6

12. Lepak, D., \& Snell, S. (1998) Virtual HR: Strategic human resource management in the $21^{\text {st }}$ century, 8(3), 215-234. doi: 10.1016/S1053-4822(98)90003-1

13. Manuti, A., \& de Palma, P.D. (2018). How to Develop Digital HRM Practices in the Cognitive Technology Era: Evidences from a Case Study. Digital HR, 67-79. doi: 10.1007/978-3-319$\underline{60210-3 \quad 5}$

14. Marler, J.H., \& Parry, E. (2016). Human resource management, strategic involvement and e-HRM technology. The International Journal of Human Resource Management, 27(19), 2233-2253. doi: $10.1080 / 09585192.2015 .1091980$

15. Mathis, R., \& Jackson, J. (2020). Human Resource Management. $13^{\text {th }}$ ed. St. Paul, MN: West Publishing Company. p. 20.

16. Nivlouei, F.B. (2014). Electronic Human Resource Management System: The Main Element in Capacitating Globalization Paradigm. International Journal of Business and Social Science, 5(2), 147-159.

17. Rebolledo, O., \& Vega, D.C. (2021). The evolution of the Human Capital concept and the challenges for the Strategic Human Resource Management in Chile. Revista gestion de las Personasy Tecnologia, 14(40), 38-59.

18. Zarkan, I. (2017). Human Resource Development in the Era of Technology; Technology's Implementation for Innovative Human Resource Development. Journal of theory \& Applied Management, 10, 3. doi: $10.20473 /$ jmtt.v10i3.5967

19. Shuler R., Jackson S. Strategic human resource management. $2^{\text {nd }}$ ed. UK: Blackwell Publishing Ltd., 2007. p.129.

20. Sleezer, C.M, Wentling, T.L., \& Cude, R.L. (Ed). Human Resource Development and Information Technology: making global connections, USA: Kluwer Academic Publisher, 2002, p. 89.

21. Stanton, J., \& Coovert, M., (2004) .Turbulent Waters: The Intersection of Information Technology and Human Resources, Syracuse University, doi: 10.1002/hrm.20010

22. Strohmeier, S. (2007). Research in E-HRM: Review and implications. Human Resource Management Review, 17(1), 19-37. doi: 10.1016/j.hrmr.2006.11.002

23. Strohmeier, S., \& Parry, E. (2014). HRM in the digital age - digital changes and challenges of the HR profession. Employee Relations, 36(4). doi: 10.1108/ER-03-2014-0032

24. Susskind, R., \& Susskind, D. (2015). The Future of the Professions: how technology will transform the work of human experts. Oxford: Oxford University Press.

25. Swaroop, K.R. (2012). E-HRM and how IT well Reduce the cost in organization. Journal of Marketing \& Management Review, 1(4), 133-139.

26. Tomashevsky, K.L. (2020). Digitalization and its impact on the labor market and labor relations (theoretical and comparative legal aspects). Vestnik of St. Petersburg State University. Law = Vestnik Sankt-Peterburgskogo universiteta. Pravo, 11(2), 398-412. (In Russ.) doi: 10.21638/ spbu14.2020.210

27. Voermans, M., \& Veldhoven, M.V. (2007). Attitude towards E-HRM: An empirical study at Philips. Personnel Review, 36(6), 887-902. 


\section{Information about the author}

Mohamad Tawbe - PhD student, Department of Management, Business Technologies and Sustainable Development. Belarusian State Technological University (13a, Sverdlova str., 220006, Minsk, Republic of Belarus); protection monitor in NGO organization funded by UNHCR (Badaro street, Beirut, Lebanese Repablic); e-mail: m.tawbe@outlook.com

ARTICLE INFO: received March 2, 2021; accepted June 4, 2021

\section{Информация об авторе}

Таубе Мохамад - аспирант кафедры менеджмента, технологий бизнеса и устойчивого развития, Белорусский государственный технологический университет (Республика Беларусь, 220006, Минск, ул. Свердлова, 13а); наблюдатель в НПО, финансируемой УВКБ ООН (Ливан, Бейрут, улица Бадаро); e-mail: m.tawbe@outlook.com

ИНФОРМАЦИЯ О СТАТЬЕ: дата поступления 2 марта 2021 г.; дата принятия к печати 4 июня 2021 г. 